\title{
Meningiomas of the lateral ventricles. A review of 10 cases
}

\author{
M. Gelabert-González; A. García-Allut; J. Bandín-Diéguez; R. Serramito-García and R. Martínez-Rumbo
}

Neurosurgical Service. Clinic Hospital of Santiago de Compostela. Department of Surgery. University of Santiago de Compostela. Spain.

\section{Summary}

Background. Intraventricular meningiomas are rare tumours that represent about $2 \%$ of all intracranial meningiomas, and represent one of the most challenging problems in neurosurgery. They are located deep within the brain and often are sizable and highly vascular. We report on a series of 10 meningiomas of the lateral ventricles treated at our institution during the last 28 years.

Patients. Ten patients (6 women, 4 men; mean age $41.6 \mathrm{yrs}$ ) were admitted to our medical center between 1978-2005 with meningioma of the lateral ventricles. Headache was the first symptom in 8 cases and ocular signs were present in 5 patients.

Results. Seven tumours were located in the right ventricle $(70 \%)$ ranging in size from $2-8 \mathrm{~cm}$, with 7 tumours larger than $3 \mathrm{~cm}$ in diameter. Nine patients underwent surgery with total excision in 8 cases and subtotal in the other; the remaining patient only received radiosurgery.

Conclusions. Total resection is the gold standard for treatment which was possible in all but one of the cases undergoing surgery.

KEY WORDS: Brain tumours. Intraventricular meningiomas. Lateral ventricle. Surgical approaches. Surgical treatment.

Meningiomas de los ventriculos laterales. presentación de 10 casos

Resumen

Introducción. Los meningiomas intraventriculares son neoplasias poco frecuentes que constituyen alrededor del $2 \%$ de todos los meningiomas intracraneales.

Pacientes y métodos. Revisamos 10 pacientes (6 mujeres, 4 varones; media de edad: 41.6 años) diagnos-

Recibido: 15-12-07. Aceptado: 12-02-2008 ticados en nuestro servicio de neurocirugía entre 19782005 de meningioma de ventrículo lateral.

Resultados. El síntoma de debut fue la cefalea en 8 casos y en 5 pacientes existían alteraciones oculares. Siete tumores estaban localizados en el ventrículo derecho $(70 \%)$ con un tamaño que oscilaba entre 2 y $8 \mathrm{~cm}$.; 7 tumores tenían más de $3 \mathrm{~cm}$. de diámetro. Se intervino quirúrgicamente a 9 pacientes consiguiéndose una extirpación completa en 8 casos y subtotal en el otro; el paciente restante fue tratado mediante radiocirugía estereotáctica.

Conclusiones. La resección completa es el tratamiento idóneo en los meningiomas intracraneales, que exceptuando un caso fue posible en todos nuestros pacientes operados.

PALABRAS CLAVE: Abordajes quirúrgicos. Meningioma intraventricular. Tratamiento quirúrgico. Tumor cerebral. Ventrículo lateral.

\section{Introduction}

Intraventricular meningiomas are uncommon tumours that represent about $2 \%$ of all intracranial meningiomas, which in turn account for 12 to $20 \%$ of all intracranial tumours s, $4,8,10,23,31$.

In a review of 500 cases of meningioma from the Academic Department of the National Hospital, Queen Square (London), Criscuolo and Symon ${ }^{6}$ reported 10 cases in the ventricles with a $2 \%$ incidence rate. Eighty percent of intraventricular meningiomas occur in the lateral ventricles, $15 \%$ in the posterior third ventricle, and $5 \%$ in the fourth ventricle. The incidence of ventricular meningiomas is higher in paediatric patients. Germano et a ${ }^{15}$ reviewed 15 series of paediatric meningioma in the literature totalling 278 meningiomas, of which $9.4 \%$ were intraventricular; $61 \%$ occurred in the 1 to 20 -year-old age group and $39 \%$ occurred in patients under 10 .

We reviewed 10 lateral ventricle meningiomas operated on from 1978 to 2005 , which account for $2.2 \%$ of the 453 intracranial meningiomas operated on in this period. 


\section{Patients and methods}

We retrospectively studied 10 patients (6 females and 4 males) with intraventricular meningiomas that were evaluated and treated in our Neurosurgical Service between 1978 and 2005. The medical records, surgical records, imaging studies and histological diagnosis, were analysed. Follow-up time ranged from 6 months to 22 years.

\section{Results}

The patient age range from 12 to 62 years (mean 41.6 ). The initial symptoms were: headache in 8 patients ( 4 cases continuous, 3 intermittent and 1 sudden), focal deficits in 1 patient (hemiparesis), and mental deterioration in another. Case 9 was a 35-year old patient diagnosed for neurofibromatosis type II with multiple prior interventions (4 intracranial meningiomas) with bilateral vestibular schwannomas, and an intraventricular meningioma diagnosed 2 year earlier. The interval between the first symptom and admission ranged from 1 day to 2 years (average duration, 18.9 weeks). On neurological examination the most common sign was homonymous hemianopsia (4 cases), papilledema ( 3 cases), and hemiparesis in 3 patients. Dysphasia was apparent in 1 case (case 4) with a left trigonal tumour (Table 1).

In all patients preoperative cranial computer tomography with and without contrast was performed. All tumours showed slight increased density; lobulation was found in three cases and irregular margins in one, calcification was observed in two cases. Contrast enhancement was present in all tumours; enhancement was homogeneous in 9 cases and heterogeneous in 1 . In 3 cases obstruction of the occipital horn resulted in dilatation of this portion of the ventricle and low density in the surrounding area due to transependymal flow of the cerebrospinal fluid and vasogenic oedema. Seven tumours were located in the right lateral ventricle and three were in the left lateral ventricle. Tumour size ranged from $2-8 \mathrm{~cm}$, with 3 tumours $(30 \%)<3 \mathrm{~cm}$ and 7 tumours $(70 \%)>3 \mathrm{~cm}$ in diameter.

Magnetic resonance imaging (MRI) was performed in 7 patients. In all cases, the tumours were isointense on T1 weighted images and homogeneous gadolinium enhancement was present in 6 patients, and heterogeneous in 1 patient (Figure 1). On T2-weighted images the tumours were hyperintense. Signal voids because of calcification were visible in two cases.

Carotid and vertebral angiography was performed in six cases and enlargement, tortuosity, and displacement of the anterior choroidal artery were observed in all cases. The tumour vascular blush was clear enough to completely outline the tumour in four cases.

In six cases the tumours were resected via a posterior parieto-occipital transcortical approach. Three tumours were resected via a transtemporal approach, in 8 patients total removal of the tumour was achieved. All ventricular meningiomas showed an attachment to the choroid plexus. Following removal of the tumours, an intraventricular

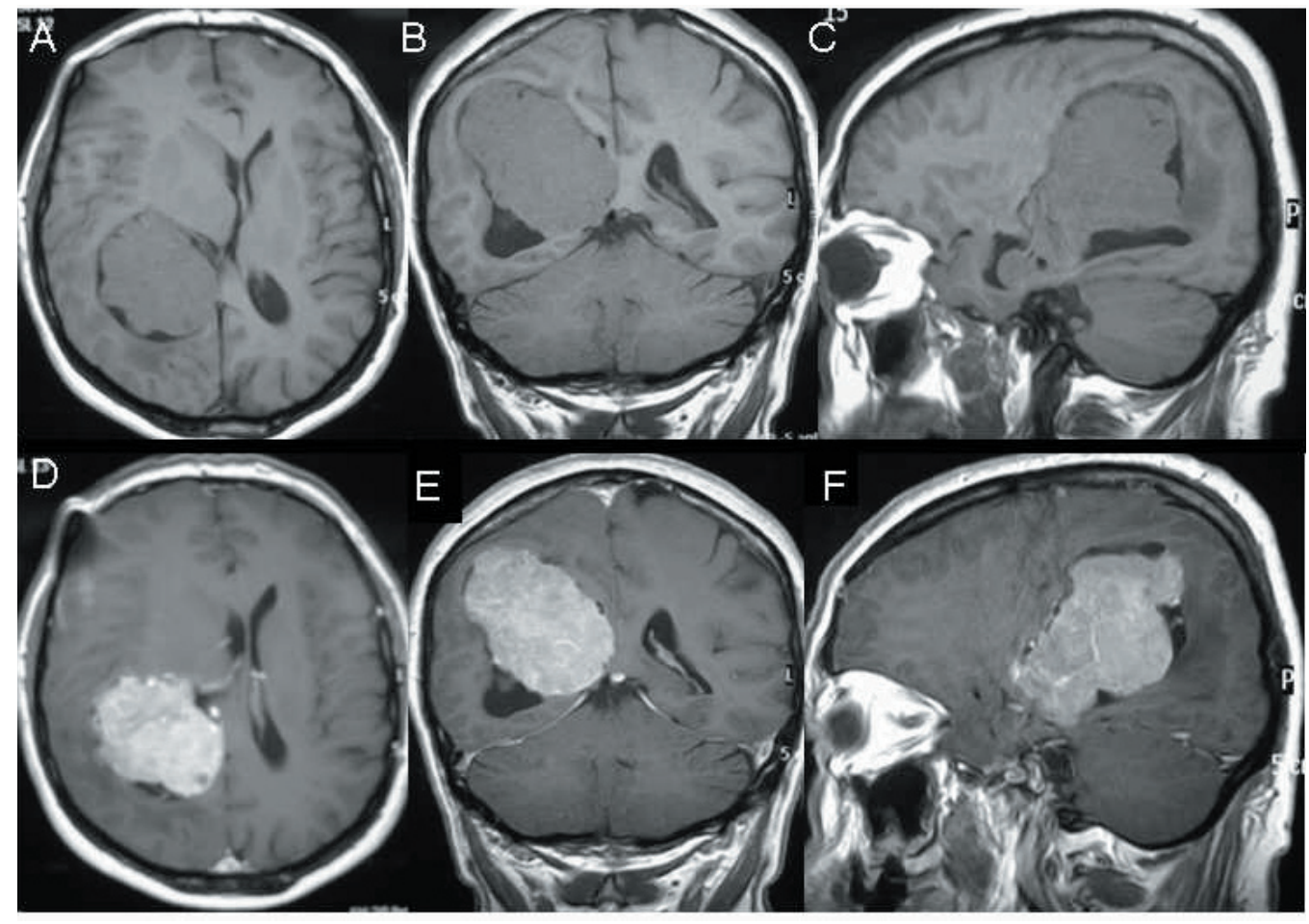

Figure 1. T1-weighted MR images without contrast show an isointense well-defined tumour in the right trigone and trapping of the right occipital horn (A-BC). Tl-weighted contrast-enhancement MR ima-ges show intense relatively homogeneous en-hancement (D-E-F) (Case 8). 


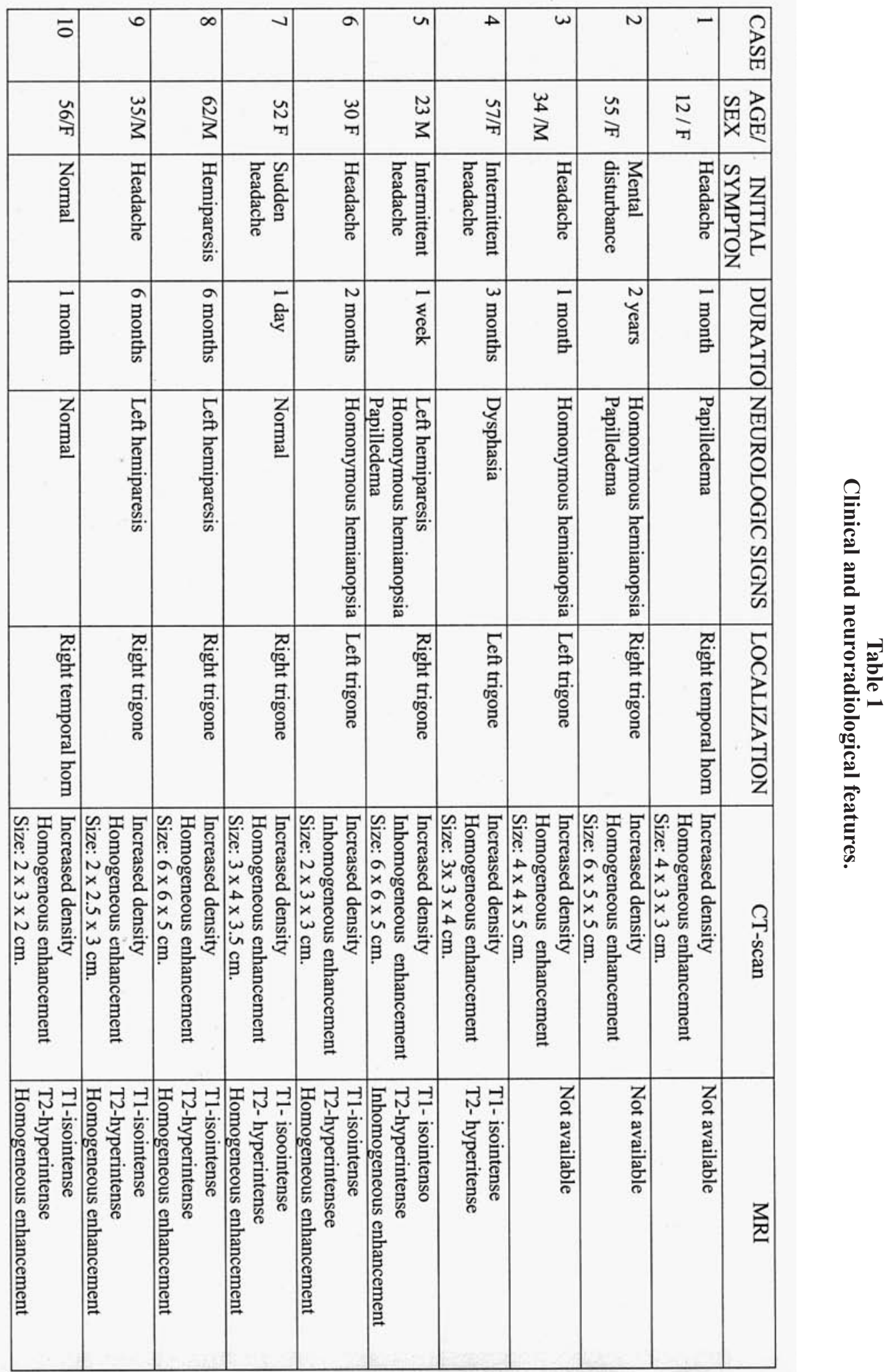


drain was left in 7 patients for 3-8 days. No intraoperative mortality was recorded though in the youngest patient of the series (dating back to 1978) total resection was complicated by a postoperative intraventricular haemorrhage leading to death $72 \mathrm{~h}$ postoperatively.

The patient 5 presented postoperative enterobacter cloacae meningitis, infection of the osteoplastic flap, communicating hydrocephalus and a ventricle-peritoneal shunt was implanted two months later.

The most common neurological deficit on follow-up was visual field disturbance. Headache and papilledema resolved in all cases. Four patients $(40 \%)$ had postoperative seizures, which were controlled by appropiate antiepileptic medication.

Histological examinations revealed 6 meningothelial meningiomas, 1 psammomatous, 1 fibrous, and 1 atypical.

The follow-up period for the 8 surviving patients ranged from 6 months to 22 years (average, 7 years). No recurrence was observed.

\section{Discussion}

Meningiomas are the second most common primary brain tumour in adults and account for 12 to $20 \%$ of all intracranial tumours, of which $2.5 \%$ are intraventricular ${ }^{4,16,23,33}$; in our series intraventricular meningiomas accounted for $2,2 \%$ of intracranial meningiomas. The first intraventricular meningioma was reported in 1854 by Shaw ${ }^{18,36}$, who described a hard, fibrous tumour located in the ventricular trigone found at autopsy in a patient who had presented language disturbances and epilepsy. Thereafter, similar cases were reported by MacDowall in $1881^{27}$ and Dreifus in $1923^{11}$. The first surgical reported case was performed by H. Cushing ${ }^{7}$ in 1916, the patient was still alive 21 years later. In their monograph on meningiomas published in 1938, Cushing and Eisenhardt ${ }^{7}$ reported having operated on two other intraventricular meningiomas. In 1965, Delandsheer presented a review of 175 meningiomas of the lateral ventricles culled from the literature ${ }^{9}$. In an earlier extensive review of the published literature up to 1986, Criscuolo and Symon $^{30}$ identified 400 intraventricular meningiomas ${ }^{6}$, and Nakamura et al in 2003 reviewed 532 intraventricular meningiomas; of these 414 occurred in the lateral ventricles $(77.8 \%), 15.6 \%$ in the third ventricle and $6.6 \%$ in the fourth ventricle.

In our series $70 \%$ were women and in general female preponderance is reported in all series and varies from $41 \%$ to as high as $82 \% \%^{2,6,23,31}$. In our series the mean age was 41.6 years whereas the mean age reported for the other series varied from 20 to 60 years ${ }^{2,4,10,13,23}$. Though in children meningiomas constitute only $1-4 \%$ of all intracranial tumours, an intraventricular location was found in $9.4 \%$ $19 \% 0^{12,15,23,26,29}$.
Meningiomas arise within the ventricle from the choroid plexus or from the tela choroidea in the ventricular system. As pointed out by Cushing and Eisenhardt ${ }^{7}$, meningiomas in the ventricle tend to assume the shape of the ventricle in which they lie. Intraventricular tumours expand, increasing the capacity of the ventricle; this occurs through local dehydration, neural cell loss and white matter atrophy. Volume parameters may be complicated by exclusion of the ventricle from the CSF circulation associated to elevation of CSF proteins ${ }^{21}$. Most meningiomas of the lateral ventricles originate in the posterior portion of the lateral ventricles, particularly, in the region of the trigone ${ }^{23}$. They rarely arise in the region of the foramen of Monro and there is a mild preponderance of lesions on the left side ${ }^{17,23}$.

Meningiomas of the lateral ventricles present mainly signs of increased intracranial pressure ${ }^{2,23,24,31}$. Symptoms and signs frequently include headache, disturbed mentation, motor and sensory deficits, seizures, visual deficits, and ataxia ${ }^{2,14,23}$. Some of the early symptoms are intermittent due to recurrent blocking of the CSF circulation ${ }^{17}$. As fibres of the geniculocalcarine tract run lateral and inferior to the atrium, they account for the visual symptoms observed in larger tumours ${ }^{28}$.

CT-scan meningiomas in the lateral ventricles are slightly hyperdense, with well-defined contours that may be smooth or irregular. In about $50 \%$ of cases, a thin ring of peritumoral hypodensity, attributable to white matter oedema, can be observed ${ }^{2,23,28}$. In some cases there may also be hypodense areas in the centre of the mass, which is indicative of tissue necrosis. Calcifications were found in $25 \%$ of reported cases ${ }^{2,14}$. Postcontrast CT-scan normally shows and intense and homogeneous enhancement ${ }^{30}$.

MRI revealed superior anatomic detail compared with CT scans, with meningiomas being iso-or hypointense on T1-weighted images and T2-weighted images. On T1-weighted postcontrast images, there was uniform contrast enhancement ${ }^{23,28}$. MR spectroscopy may provide additional information in cases in which the differential diagnosis of tumours by neuroimaging is difficult. The most common proton spectrum found in meningiomas is a high choline peak with low or absent $\mathrm{N}$-acetylaspartate and phosphocreatine (present only in neuronal tissue) and variable amounts of lactate. Most important, an usually high ratio of alanine to phosphocreatine has been found in meningiomas because of the high alanine and low phosphocreatine content, which is a relatively specific finding for meningiomas ${ }^{20,25}$.

Currently, cerebral angiography is rarely used as intraventricular meningiomas can rarely be embolized. Angiography can confirm the predominant blood supply and the position of prominent parasagittal draining veins ${ }^{28}$. The arterial phase almost always reveals an anterior choroidal artery supply and the artery itself appears enlarged, 
tortuous, and displaced, more frequently homolaterally and less frequently contralaterally. In approximately $50 \%$ of cases, the afferences coming from the medial and lateral posterior choroidal supply are easily visible ${ }^{2}$. The venous phase permits identification of the drainage veins that flow either into Galen's ampulla or directly through the internal cerebral vein or Rosenthal's basal vein ${ }^{18}$.

Surgery is the gold standard of treatment for symptomatic intraventricular meningiomas, because complete excision can be accomplished, and cures can be achieved ${ }^{28}$.

The number of reports regarding surgical techniques for attacking this type of tumour multiplied following Cushing's initial publications regarding successfully operated meningiomas of the lateral ventricles ${ }^{7}$. Various surgical approaches to lateral ventricular meningiomas have been advocated; for trigonal tumours, Cushing ${ }^{7}$ proposed a temporoparietal approach. In $1960 \mathrm{Cramer}^{5}$ mentioned the merits of a posterior parieto-occipital approach, and Fornari et $\mathrm{al}^{13}$ systematically used this technique in their 1981 series. Olivecrona ${ }^{32}$ suggested a posterior middle temporal gyrus approach also recommended by Criscuolo and Symon ${ }^{6}$. The surgical approach selected should be the one that affords optimum anatomical exposure of the tumour and its vascular supply which depends largely on the surgeon's personal experience ${ }^{1,22,34}$. Ideally, the approach chosen should ensure sufficient exposure to permit piecemeal removal of the tumour, allow rapid identification of the supplying vessels so they can be divided promptly, avoid excessive brain retraction, and limit damage of functional cortex ${ }^{34,35}$.

Meningiomas of the frontal horn or close to the foramen of Monro raise no technical problems; these are attacked, by the transfrontal route ${ }^{17}$; however most meningiomas of the lateral ventricles lie at the trigonal level and several approaches have been described.

The interhemispheric transcallosal approach described by Kempe and Blaylock ${ }^{19}$ was used by some authors to attack tumours of the left trigone with excellent results. This approach is preferred if the tumour is small, located near the midline, and does not require excessive hemispheric retraction and provides early exposure and obliteration of the feeding branches of the posterior choroidal artery and medial drainage veins. The complications of this route are well reported and include hemiparesis, aphasia, mutism, confabulations, memory deficits ${ }^{1}$.

The posterior middle temporal gyrus incision, used in two of our cases, was described initially by Olivecrona ${ }^{32}$. This approach is greatly facilitated when the temporal horn is dilated and offers the advantage of earlier identification of the anterior choroidal vessels, usually the main afferences of the tumour. Language function in the dominant hemisphere may be compromised in any case. Homonymous field cuts are also seen with this approach but damage to the visual projection fibbers (Meyer's loop) is generally slight, as the cortical incision lies parallel to them ${ }^{6}$.

The parieto-occipital approach can be selected for either the left or right side but is most often employed for dominant hemisphere tumours. It is probably the most popular approach for ventricular meningiomas; the choroidal vessels, usually lying underneath, can be controlled after debulking the tumour by piecemeal removal. A possible complication is permanent visual field impairment as the optic radiations runs inferolaterally to the ventricles though the ventricular trigone can be reached through a parietooccipital route without interrupting the optic radiation ${ }^{22,30}$.

The most common complications described are severe brain oedema, intraventricular haemorrhage, subdural or epidural haematoma, and additional neurologic deficits ${ }^{3}$. The risk of postoperative seizures has been noted to be higher with transcortical routes than with transcallosal approaches ${ }^{13}$. The operative mortality reported in the majority of the series ranged from 0 to $42 \%$.

One of our patients, who rejected surgery, was treated using fractionated radiosurgery; although the efficacy of this treatment has not been established and there have as yet been few reports ${ }^{37}$. Reports of $85 \%$ to $98 \%$ tumour control rates achieved with radiosurgery cannot be overlooked during the informed consent procedure ${ }^{28}$.

In conclusion, meningiomas of the lateral ventricles of the brain are rare tumours, accounting for approximately $2 \%$ of all intracranial meningiomas. CT and MRI enable a correct diagnosis of intraventricular meningiomas in most of the cases. The operative route should be selected according to the tumour location. The parieto-occipital transcortical route for resection of trigonal meningiomas is a safe surgical approach, which is not necessarily associated with postoperative visual deficits.

\section{Acknowledgements}

The authors thank Mr. Romen Das Gupta for his assistance in the preparation of this paper.

\section{References}

1. Apuzzo, M.L., Chikovani, O.K., Gott, P.S., et al. Transcallosal, interforniceal approaches for lesions affecting the third ventricle: surgical considerations and consequences. Neurosurgery 1982; 10: 547-554.

2. Bertalanffy, A., Roessler, K., Koperek, O., Gelpi, E., Prayer, D., Neuner, M., Knosp, E.: Intraventricular meningiomas: a report of 16 cases. Neurosurg Rev 2006; 29: 30-35.

3. Bret, P., Gharbi, S., Cohadon, F., Remond, J. Les méningiomes du ventricule latéral. 3 observations récentes. Neurochirurgie $1989 ; 35: 5-12$. 
4. Caner, H., Acikgoz, B., Ozgen, T., Colak, A., Onol, B.: Meningiomas of the lateral ventricle. Report on six cases. Neurosurg Rev 1992; 15: 303-306.

5. Cramer, F.: The intraventricular meningiomas: a note of the neurologic determinants governing the surgical approach. Arch Neurol 1960; 3: 98.

6. Crisuolo, G.R., Symon, L.: Intraventricular meningioma. A review of 10 cases of the National Hospital, Queen Square (1974-1985) with reference to the literature. Acta Neurochir (Wien) 1986; 83: 83-91.

7. Cushing, H., Eisenhardt, L.: Meningiomas: their classification, regional behaviour, life history and surgical end results. Springfield, Illinois: Charles C. Thomas. 1938.

8. Delfini, R., Acqui, M., Oppido, P.A., Capone, R., Santoro, A., Ferante, L.: Tumors of the lateral ventricles. Neurosurg Rev 1991; 14: 127-133.

9. Delandsheer, J.M.: Les méningiomes du ventricule latéral. Neurochirurgie 1965; 11: 4-83.

10. Domínguez, J., Lobato, R.D., Rivas, J.J., Gómez, P.A., Cabrera, A., Castañeda, M., Ortega, J.M.: Meningiomas de los ventrículos laterales. Presentación de 7 casos. Neurocirugía 1990; 1: 359-365.

11. Dreifus, W.: Ueber endothelium des plexus choroideus. Beitr Path Anat 1923; 71: 667-673.

12. Ferrante, L., Acqui, M., Artico, M., Mastronardi, L., Rocchi, G., Fortuna, A.: Cerebral meningiomas in children. Child's Nerv Syst 1989; 5: 83-86.

13. Fornari, M., Savoiardo, M., Morello, G., Solero, C.L.: Meningiomas of the lateral ventricles.Neuroradiological and surgical considerations in 18 cases. J Neurosurg 1981; 54: 64-74.

14. Gelabert, M., Castro, A., Bandín, F.J. Intraventricular meningiomas. In: Bouzas M, Gelabert M (eds) Meningiomas. Universidad de Santiago de Compostela. 2002; pp 231-242.

15. Germano, I.M., Edwards, M.S., Davis, R.L., Schieffer, D.: Intracranial meningiomas of the first two decades of life. J Neurosurg 1994; 80: 447-453.

16. Gokalp, H.Z., Yuceer, N., Arasil, E., Deda, H., Attar, A., Erdodan, A., et al. Tumours of the lateral ventricles. Neurosurg Rev 1982; 21: 126-137.

17. Guidetti, B., Delfini, R., Gagliardi, F.M., Vagnozzi, R.: Meningiomas of the lateral ventricles. Clinical, neuroradiologic, and surgical considerations in 19 cases. Surg Neurol 1985; 24: 364-370.

18. Guidetti, B., Delfín, R.: Lateral and fourth ventricle meningiomas. In: Al-Mefty O (ed) Meningiomas. Raven Press, New York, 1991; pp 569-581.

19. Kempe, L.G., Blaylock, R.: Lateral-trigonal intraventricular tumors. A new operative approach. Acta Neurochir (Wien) 1976; 35: 233-242.

20. Kinoshita, Y., Kajiwara, H., Yokota, A., Koga, Y.: Proton magnetic resonance spectroscopy of brain tumors: an in vitro study. Neurosurgery 1994; 35: 606-614.

21. Kloc, W., Imielinski, B.L., Wasilewski, W., Stempniewicz, M., Jende, P., Karwacki, Z.: Meningiomas of the lateral ventricles of the brain in children. Child's Nerv Syst 1998; 14: 350-353.

22. Lamas, E.: Tumores de los ventrículos laterales del cerebro. IV. Tratamiento quirúrgico. In: Obrador, S., Blázquez, M.G., Soto, M et al (eds). Tumores de los ventrículos laterales del cerebro. Madrid: Ministerio de Trabajo-Instituto Nacional de Previsión, 1972; pp 119-133.

23. Liu, M., Wei, Y., Liu, Y., Zhu, S., Li, X.: Intraventricular meningiomas: a report of 25 cases. Neurosurg Rev 2006: 29: 36-40.

24. Marrero, C.L., Domínguez, J., Ramos, R., Gómez J., Lourido, J.A.: Meningioma intraventricular. Presentación de un caso en la infancia. Neurocirugía 2005; 16: 523-527.

25. Majós, C., Cucurella, G., Aguilera, C., Coll, S., Pons, L.C.: Intraventricular meningiomas: $\mathrm{MR}$ imaging and $\mathrm{MR}$ spectroscopic findings in two cases. AJNR 1999; 20: 882885 .

26. Mallucci, C.L., Parkes, S.E., Barber, P., et al: Paediatric meningeal tumours. Child's Nerv Syst 1996; 12: 582588.

27. MacDowall, T.W.: Large calcareous tumor involving chiefly the inner and middle portions of the left temporosphenoidal lobe and pressing upon the left crus and optic thalamus (brief communication). Edinburgh Med J 1881; 26 : 1088 .

28. McDermott, M.W.: Intraventricular meningioma. Neurosurg Clin N Am 2003; 14: 559-569.

29. Mircevski, M., Mircevska, D., Bojadziev, I., Basevska, R.: Surgical treatment of intraventricular meningiomas in childhood. Acta Neurochir (Wien) 1985; 35: 89-91.

30. Nakamura, M., Roser, F., Bundschuh, O., Vorkapic, P., Samii, M.: Intraventricular meningiomas: a review of 16 cases with reference to the literature. Surg Neurol 2003; 59: 491504.

31. Obrador, S., Blázquez, M.G., Soto, M.: Tumores de los ventrículos laterales del cerebro. I. Clínica. In: Obrador, S., Blázquez, M.G., Soto, M et al (eds). Tumores de los ventrículos laterales del cerebro. Madrid: Ministerio de Trabajo-Instituto Nacional de Previsión, 1972; pp 17-59.

32. Olivecrona, H., Tönnis, W.: Handbuch der Neurochirurgie. Springer, Berlin, Heidelberg, New York Vol 4, 1967; pp 175-177.

33. Pinheiro, C., Calheiros, A.L., Martins, V., Carvalho, E.: Meningiomas dos ventrículos laterais. Um estudo clinico, imagiológico e cirurgico de 3 casos operados. Neurocirugía 1997; 8: 294-301.

34. Rhoton, A.L.: The lateral and third ventricles. Neurosurgery 51 (supp 1): 2002; S207-271.

35. Santoro, A., Salvati, M., Frati, A., Polli, F.M., Delfini, R., Cantore, G.: Surgical approaches to tumours of the lateral 
ventricles in the dominant hemisphere. J Neurosurg Sci 2002; 46: 60-65.

36. Shaw, A.: Fibrous tumour in the lateral ventricle of the brain. Boney deposits in the arachnoid membrane of the right hemisphere. Trans Path Soc London 1853; 5:18-21.

37. Terada, T., Yokote, H., Tsuura, M., Kinoshita, Y., Takehara, R., Kubo, K., Nakai, K., Itakura, T.: Presumed intraventricular meningioma treated by embolisation and gamma knife. Neuroradiology 1999; 41: 334-337.
Gelabert-González, M.; García-Allut, A.; Bandín-Diéguez, J.; Serramito-García, R.; Martínez-Rumbo, R.: Meningiomas of the lateral ventricles. A review of 10 cases. Neurocirugía 2008; 19: 427-433.

Author address: Miguel Gelabert-Gonzalez. Neurosurgical Service. Hospital of Santiago. La Choupana 15706 Santiago de Compostela. Spain. 